Z. klin. Chem. u. klin. Biochem.

8. Jg., S. 190-196, Mai 1970

\title{
Nicotine and Arteriosclerosis
}

\author{
An Experimental Contribution to the Influence of Nicotine on Fat Metabolism \\ By H. Schievelbein, V. Londong, W. Londong, H. Grumibach, V. Rị \\ Institut für Kliniscbe Chemie und Kliniscbe Biocbemie der Universität München \\ (Direktor: Prof. Dr. Dr. E. Werle)
}

A. Schauer

Pathologisches Institut der Universität Miinchen

(komm. Direktor: Prof. Dr. W. Büngeler)

and

\author{
H. IMMICH \\ Institut für Dokumentation, Information und Statistik am Deutschen Krebsforschungszentrum Heidelberg \\ (Direktor: Prof. Dr. G. Wagner)
}

(Eingegangen am 9. Februar 1970)

Rabbits were given $1.14 \mathrm{mg}$ nicotine per $\mathrm{kg}$ body weight twice daily for 20 months. The following results were obtained:

1. Total cholesterol, total lipids, esterified fatty acids and phospholipids ate increased towards the middle of the experiment and approximate to the starting values at the end of the experiment. There are no differences between nicotine-treated animals and controls.

2. Free fatty acids in the blood of nicotine-treated animals are elevated after 8 months, less so after 12 months and the same as the controls after 20 months; these changes, however, are not statistically significant. The qualitative composition of the esterified fatty acids in the blood of the nicotine-treated animals shows no difference as compared to the controls.

3. $\beta$-Lipoproteins and $\beta$-lipoprotein cholesterol in the blood of the nicotine-treated animals were not increased after 20 months.

4. In nicotine-treated animals, the above lipids show no increase in heart, liver and aorta, with the exception of free fatty acids, which are elevated in liver and aorta. In the liver, the neutral fat is significantly decreased in nicotine-treated animals.

5. The activity of lipoprotein lipase is intensively increased in heart and aorta of the nicotine-treated group.

6. The content of calcium in the aorta of the nicotine-treated group is significantly increased.

7. Histologically changes are observed, which in addition to other pathological findings, show a tendency to develop arteriosclerosis, but these changes could be observed in the nicotine treated and the control group with the same frequency and to the same extent.

8. When the animals were sacrificed after 20 months, the following further results were obtained:

In the blood of the test animals, no alterations were observed in: serum enzymes, proteins, red and white blood cell count, electrolyte content, level of urea and blood sugar.

9. It is concluded from these results: Statistical-epidemiological correlations between the morbidity of coronary heart disease and cigarette smoking can not be explained by the pharmacological effect of nicotine alone, which, through the release of catecholamines, is lipolytic. Investigations on further smoke constituents are indicated with regard to coronary heart disease.

Kaninchen erhielten während 20 Monate $1,14 \mathrm{mg} / \mathrm{kg}$ Nikotin $2 \mathrm{mal}$ täglich, die folgenden Ergebnisse wurden erhalten:

1. Im Blut sind das Gesamtcholesterin, Gesamtlipide, die veresterten Fettsäuren und die Phosphatide nach 12 Monaten erhöht und sind gegen Ende des Experimentes wieder gleich den Ausgangswerten. Unterschiede zwischen den nikotinbehandelten und den Kontrolltieren besteben nicht.

2. Die freien Fettsäuren im Blut der nikotinbehandelten Tiere waren nach 8 Monaten erhöht, nach 12 Monaten weniger stark erhöht und gleich denen der Kontrollen nach 20 Monaten. Dieser Unterschied war statistisch nicht signifikant. Die qualitative Zusammensetzung der veresterten Fettsäuren im Blut der nikotinbehandelten Tiere war nicht verschieden von derjenigen der Kontrollen.

3. $\beta$-Lipoproteine und $\beta$-Lipoproteincholesterin waren nach 20 Monaten nicht verschieden zwischen beiden Gruppen.

4. Die erwähnten Lipoide waren nicht erhöht in Herz, Leber und Aorta der nikotinbehandelten Tiere, mit Ausnahme der freien Fettsäuren, welche in Leber und Aorta signifikant erhöht waren. In der Leber der behandelten Tiere war der Neutralfettgehalt erniedrigt.

5. Die Aktivität der Jipoproteinlipase war erhöht in Herz und Aorta der behandelten Tiere.

6. Der Calciumgehalt der Anrta der behandelten Tiere war erhöht.

7. Histologisch konnten Veränderungen beobachtet werden, welche, neben anderen pathologischen Befunden, die Tendenz zur Entwicklung einer Arteriosklerose zeigten, diese Veränderungen wurden jedoch in behandelten und unbehandelten Tieren in der gleichen Häufigkeit und dem gleichen Ausmaß beobachtet.

8. Nach Tötung der Tiere nach 20 Monaten wurden die folgenden weiteren Befunde erhoben:

Keine Veränderung wurde im Blut der nikotinbehandelten Tiere gefunden bei: Serumenzymen, Serumproteinen, rotem und weißem Blutbild, Elektrolytgehalt, Harnstoffspiegel und Blutzuckerspiegel.

9. Es wird aus den Ergebnissen geschlossen: Statistisch-epidemiologische Beziehungen zwischen der Morbidität an coronaren Herzerkrankungen und Zigarettenrauchen können durch die pharmakologischen Wirkungen des Nikotins allein nicht erklärt werden, welches auf dem Wege der Freisetzung von Catechinaminen lipolytisch wirkt. Weitere Untersuchungen im Hinblick auf die Beteiligung anderer Raucbbestandteile in bezug auf die coronaren Herzerkrankungen sind angezeigt. 
In several retrospective and prospective statisticalepidemiological studies, cigarette smoking has been connected with coronary heart discase $(1,2)$. In the so called „Framingham Study" (3) cigarette smoking has becn recognized as a "tisk factor", which, together with other factors, may lead to an earlicr manifestation of coronary heart disease in smokers than in nonsmokcrs. From a statistical point of view, the relation between coronary heart disease and cigarette smoking is not very strong (4), but considering the very high mortality by coronary heart diseasc, all risk factors are of eminent importancc. With regard to the influence of tobacco smoke very little is known about the mechanism, which may possibly contribute to the manifestation of coronary heart diseasc.

In an autoptic study on patients who had died of other than heart discases, AurkBaCir (5) showed that smokers had earlier histologically demonstrable manifestations of coronary sclerosis than non-smokers; morcover the extent of coronary sclerosis has been stated by Auerbacir to be correlated with the number of cigarettes consumed. From these and other investigations it may be concluded, that the main cause of coronary heart disease is coronary sclerosis. With regard to the influence of tobacco smoke, the problem arises as to which constituent of the smoke is responsible for the effect described.

Administration of nicotine leads to the relcasc of catecholamines, especially from the adrenal medulla. This has been proved by the finding of increased excretion of catecholamines and their metabolites in the urine of smokers $(6,7)$. In addition to the pharmacological efiects, especially increase of blood pressure, the relcase of adrenaline and noradrenaline cause metabolic effects when relcased, namely increase of the blood sugar level and rise of the concentration of free fatty acids in the blood.

The relense of free fatty acids by nicotine vin release of cntecholamines and subscquent activation of the triglyceride esterase of adipose tissuc has been shown to occur in experimental animals (8) and also in humans (9). Because it has becn proved, that this effect takes place also after administration of tobaceo smoke we can assume, that this effect is duc to the pharmacological effects of nicorine.

With regard to these facts, several authors have tried to evaluate the effect of nicotine on experimental arteriosclerosis and on fat metabolism in humans. CzochraIysanowics (10), Thienes (11), Hass (12), and GrosgoGEAT (13), using different experimental assays, observed an increasc of arteriosclerotic changes, following the administration of nicotinc to rabbits fed an arteriogenic dict.

Several investigators found elevated blood cholesterol levels after nicotine administration $(10,13,14)$. In humans contradictory results have been obtained; increased cholesterol levels in smokers have been found by GOIMAN (15), KARVONEN (16), BRONTE-STEWARI' (17), and KANNEL (18). The concentration of $\beta$-lipoprotcins in the blood of smokers has been found by nearly all the above authors to be elevated, whilc the levcl of triglycerides in smokers was mostly unchanged $(19,20$, $21,22)$ or decreased $(23,24)$.

The above mentioned experiments were performed generally for a relatively short period; nicotine has been used in addition to other arteriogenic factors, especially cholesterol feeding. Because of the above mentioned results and the pharmacological actions of nicotine, we investigated the effect of nicotine in the rabbit under the prolonged influence of moderate doses in order to approximatc as closely as possible the conditions of smoking. The diet was normal and conditions were constant. At the same time, the biochemical and morphological effects of chronic nicotine administration were tcsted.

\section{Material and Methods}

White New Zenland female rabbits aged 40 days wore divided into a nicotine treated group $(n=35)$ and concrols $(n=25) . \Lambda t$ the end of the experiment (mean life time $=20$ months) 22 animals of the nicotine trentcel group and 17 animals of the control group were still living. 2 months affer the start of the experiment: several animals fell sick with coccidiosis. Therefore all animals were treated with a sulfonamide preparation (Ganda $V i t \Lambda+D_{3}$ $+\mathrm{j}$ ) and a vitamin preparation (Vitamin-Komplett VitaminBCK) (both preparations Dr. Rentschler \& Co., lauphcim). 3 months later several animals suffered from a catarrhalic infection of the upper airways which was treated with parenteral applications of $100 \mathrm{mg}$ chloramphenicol (Paraxin, Bodhringer, Mannheim) subcutaneously daily*). In addition to the death of some of these animals we lost some animals from tumors of the stomach, ovaries, and the orbita. All animals received "Altromin k" (firm of Altroggc, Lage, West-Gurmany) ad libitum as standard dict without any supplement (composition in \%: taw protein 18.2; raw fibre 13.9; fat 4.9; ash 7.5; N-frec extract matcrial 45.2).

Nicotine: 'l'he experimental group received $1.14 \mathrm{mg}$ nicotine (frec basc)/kg body weight two times daily from Monday to Friday and once daily on saturdays and sundays in the drinking water. This dosage was chosen with reference to nicotine amounts administered by other authors with subsecpuent development of artcriosclerosis and with regard to human smoking behaviour. The nicotine dose was adapted during the first wecks of the experiment to the increasing weight of the still growing animals. remporary withdrawal of drinking water before administration of nicotine assured the uptake of the total nicotine dose within about 30 minutes; mureover, the nicutine concentration in the blood and in several organs has been cstimated in a further group of animals, undergoing the same treatment (sec under "results").

Weight controls were performed monthly.

Fat melabolism: 1For estimation of fat metabolites, blood was withdrawn from an car vein after 8,10 and 20 months. Withdrawal of blood was performed always at the same time of day and therefrite under the same dietetic conditions.

Jiree fatty acids: Copper method, according to Duncombe (25). Plsosplsolipids: Tistimation of organic phosphorus in protcin precipitatc according to WaCH'TBR (26). Estorified fatly acills: Hydroxamic acid method of GALETr's (27). Bonnd and froe cloolesterol with the JilimeraranN-Burchiaro reaction mudified according 10 WaTson (28). Total lipids: Vanillin method nccording to CInAlkol, and Cimarounat (29). Activity of the lipmprotein lipast' as described by ZÖLINABK and EMEMIAGizN (30).

Qualiative estimation of the esterified froction of fatly acids in scrumt and organs was performed by gas-chromatography in a FolCHSizenRY extract prepared immediatcly after sactifice. Muthylation of fatty acids (Scillusk and GelLL?KMNNN) (31). Apparatus: Hewlett-Packard Model 810, FID, metal columns $1 / 8^{\prime \prime}$, length

*) We are very grateful to Dr. H. Scinsis, Institut für Mikrobiolugie und Infekt ionskerankheiten der' l'iere der Universitit Niünchen, for diagnessis and therapeutic suggestions. 
$8 \mathrm{ft}$. Packing: $10 \%$ dicthylsuccinate on chromosorb W, AWDMCS, 80 to 100 mesh. Tempcrature: injection point: $310^{\circ}$, detector $300^{\circ}$, oven (programmated): $140-190^{\circ}, 2^{\circ}$ per minute, upper limit 20 minutes. Carrier gas: nitrogen $40 \mathrm{~m} /$ minute.

Nicotine estimation was performed by gas-chromatography according to a method published earlier by the present authors (32).

Furtber methods: Serum enzymes: aspartate transaminase (EC 2.6.1.1) (KARMEN (33)), alanine transaminase (EC 2.6.1.2) (WROBLEWSKI and LADUE (34)), I-iditol dehydrogenase (sorbitol dehydrogenase, EC 1.1.1.14) (HOLZER, HAAN and SCHNEIDER (35)), leucine aminopeptidase (EC 3.4.1.1) (NAGEL, WILLIG and SCHMIDT (36)), $\alpha$-amylase (EC 3.2.1.2) (SoMOGYI (37)), acid phosphatase (EC 3.1.3.2) (Fishuan (38)), alkaline phosphatase (EC 3.1.3.1) (BEsSEY, LOWRY and BROCK (39)), lactate dehydrogenase (EC 1.1.1.27) (WROBLEWSKI and LADUE (40)).

Hematological and other methods: Erythrocyte-, leucocyte- and thrombocyte-counting with counting chamber. Hemoglobin as cyanhemiglobin. Estimation of $\mathrm{K}^{+}, \mathrm{Na}^{+}$, and $\mathrm{Ca}^{++}$in the serum with flame photometer, urea with urease. Blood sugar enzymatically with the glucose oxidase/peroxidase-method. Serum proteins electrophoretically. Calcium estimation in aortic tissue according to FERro and HAM (41).

At the end of the experiment the animals were anesthesized by a blow on the neck and were bled from the A. carotis. The organs to be investigated were either removed and deep frozen until processing, or a FoLCH-SPERRY extract was prepared.

For the estimation of the calcium content and activity of the lipoprotein lipase of aortic tissue, exactly the same part of the vessel was always used.

Statistical methods: The given problem includes the comparison of two treatments, namely "nicotine" and "control". Moreover the effects of the factors "age" and "serum" had to be investigated, therefore the analysis of variance has been chosen as an appropriate statistical model. The analysis of variance requires assumptions as follows:
(I) Normally distributed data
(II) Homoscedasticity
(III) Balance of groups
(IV) Independency of data

Assumptions (I) and (II) have been fulfilled by transformation of the original data. The balance of groups has been produced by use of random numbers. Independence has been effected by the method of linear contrast. The effects of treatments have been considered like fix, the effects of "age" and "serum" as random.

The presentation of results of the analysis of variance renounces a display of standard deviations.
Some of the data are presented only in tables without the use of test-procedures. In these tables the standard deviations have been computed. An estimation with these parameters was not performed; because of the slight deviations of the values the distributions of the original data have not been checked.

Histoloyical methods: The aorta, main arteries, heart, kidney, liver, striated muscle, pancreas, intestine, and brain were investigated microscopically. From some of the animals the adrenals and the urinary bladder were also investigated. After formalin fixation $(10 \%)$ paraffin sections were stained with haematoxylin-eosin.

\section{Results}

\section{Body weight}

Both groups showed a normal development of body weight with no difference between the controls and the nicotine-treated animals. At the end of the experiment the mean weight of the controls was 4.04 and that of the nicotine-treated animals $4.22 \mathrm{~kg}$.

\section{Nicotine concentration}

The blood of animals treated with nicotine in the same manner as the experimental group showed in the period from 15 to 60 minutes after uptake of the whole dose 0.2 to $0.03 \mu$ gicotine $/ \mathrm{m} /$ blood. A rough balance after estimation of nicotine in faeces and urine showed that practically the whole amount administered had been resorbed and metabolized. From the stomach content, about 50\% were resorbed after 15 minutes: In several organs, brain, heart, salivary gland, adrenals, and aorta traces of nicotine could still be detected after 9 hours. This observed resorption of nicotine into depots, and especially into the walls of the blood vessels is in accordance with findings of other authors (42).

\section{Fat metabolism}

Total cholesterol, phosphatides and esterified fatty acids in the blood rise toward the middle of the lifetime of the animals and begin to fall towards the end of the experiment (fig. 1). Because the concentration of free cholesterol does not change, the rise of total cholesterol must be attributed to a change in the level of cholesterol esters. With regard to age these changes are statistically significant $(P=0.01)$. A signi-

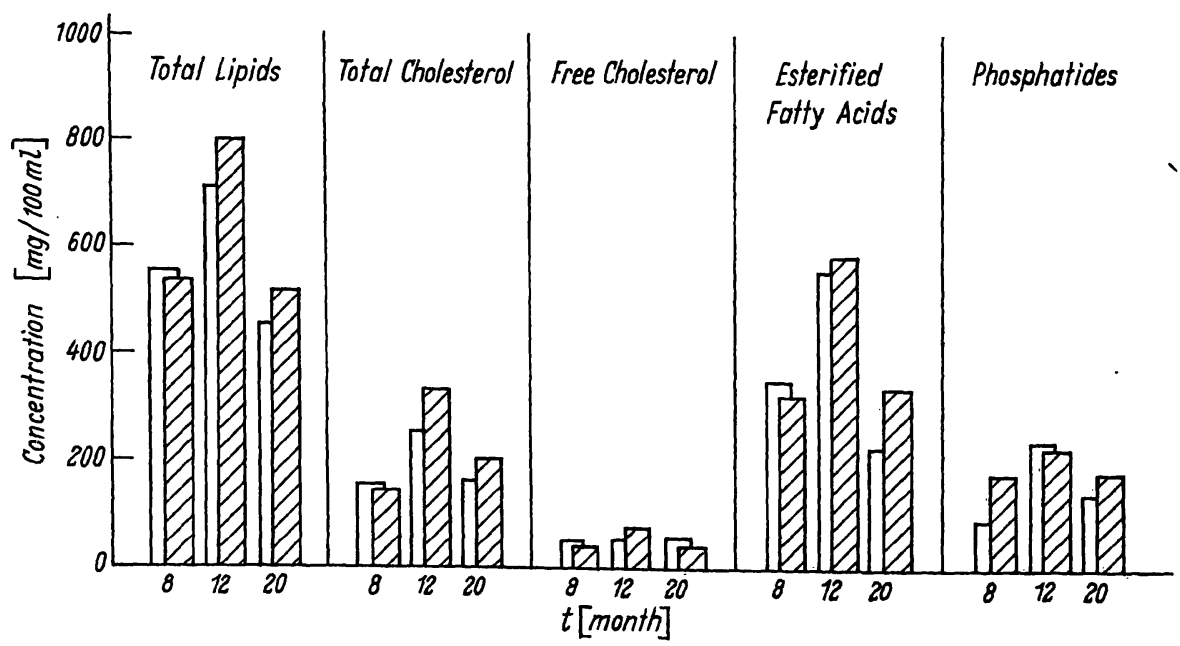

Fig. 1

Concentration of lipids in serum after 8,12 and 20 months. White bars: controls hatched bars: treated 
ficant difference between test animals and controls of the same age does not exist. The free fatty acids (fig. 2) of the serum were increased at the beginning of nicotine application, moderately elevated after 8 months and in the range of controls after 20 months. After 20 months the concentration of the $\beta$-lipoproteins of the test group $(151 \mathrm{mg} / 100 \mathrm{ml})$ was higher than that of the controls $(66 \mathrm{mg} / 100 \mathrm{~m})$. As these findings are statistically not significant they must be considered as a chance product. The values of the lipids in liver, heart, and aorta after 20 months are registered in table 1 . There is no difference between the treated and the control group. Remarkable, however, is the strongly decreased concentration of neutral fat in the liver of the nicotine-treated animals. The concentration of free fatty acids in liver, heart, and aorta is given in figure 3 , which shows that the concentration of free fatty acids in liver and aorta of the nicotine-treated group is significantly increased compared with the controls. The activity of lipoprotein lipase in aortic tissue of the nicotine treated animals is significantly higher than that of the controls (fig. 4).
In table 2 the composition of the esterified fatty acids of aorta, heart, and serum of the experimental animals is shown. There is no significant difference between controls and treated animals.

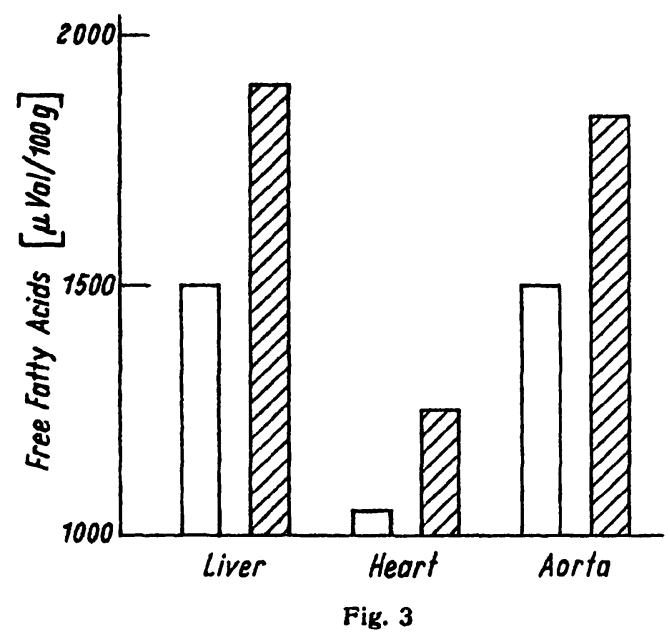

Free fatty acids in liver heart and aorta at the end of the experiment (20 months). White bars: controls; hatched bars: treated

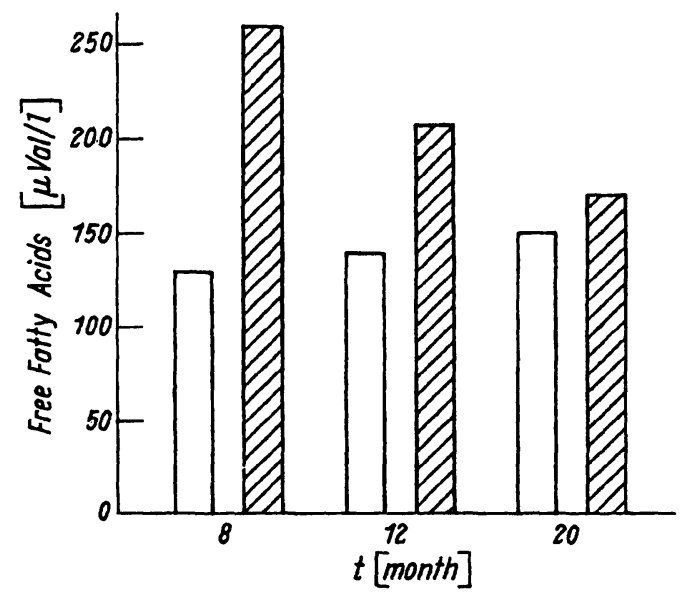

Fig. 2

Free fatty acids in the blood after 8,12 and 20 months. White bars: controls; hatched bars: treated

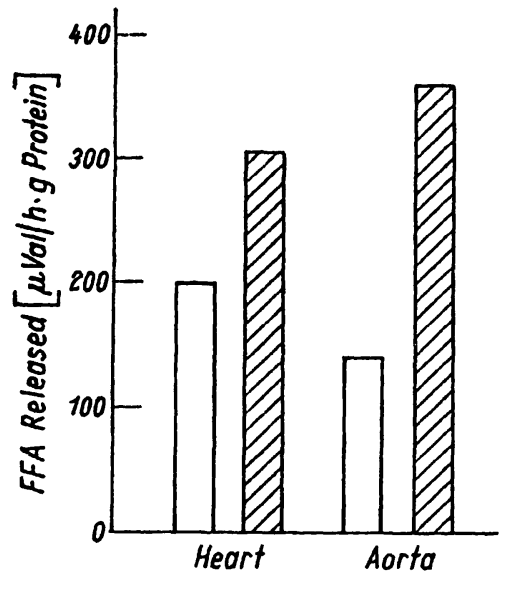

Fig. 4

Activity of lipoprotein lipase in heart and aorta after 20 months (FFA $=$ free fatty acids). White bars: controls; hatched bars: treated

Tab. 1

Lipids in organs after 20 months, values in $\mathrm{mg} / 100 \mathrm{~g}$ fresh weight, neutral fat calculated (means)

\begin{tabular}{|c|c|c|c|c|c|c|}
\hline & \multicolumn{2}{|c|}{ Heart } & \multicolumn{2}{|c|}{ Liver } & \multicolumn{2}{|c|}{ Aorta } \\
\hline & $\begin{array}{l}\text { Nicotine } \\
\text { treated }\end{array}$ & Controls & $\begin{array}{c}\text { Nicotine } \\
\text { treated }\end{array}$ & Controls & $\begin{array}{c}\text { Nicotine } \\
\text { treated }\end{array}$ & Controls \\
\hline $\begin{array}{l}\text { Total lipids } \\
\text { Total cholesterol } \\
\text { Free cholesterol } \\
\text { Esterified fatty acids } \\
\text { Phosphatides } \\
\text { Neutral fat }\end{array}$ & $\begin{array}{r}2779 \\
159 \\
80 \\
1286 \\
1573 \\
1047\end{array}$ & $\begin{array}{r}2517 \\
152 \\
53 \\
1480 \\
1569 \\
796\end{array}$ & $\begin{array}{r}3511 \\
433 \\
101 \\
1526 \\
3033 \\
45\end{array}$ & $\begin{array}{r}3603 \\
393 \\
79 \\
1548 \\
2799 \\
411\end{array}$ & $\begin{array}{r}9214 \\
291 \\
21 \\
6421 \\
675 \\
8248\end{array}$ & $\begin{array}{r}9845 \\
353 \\
23 \\
6656 \\
798 \\
8704\end{array}$ \\
\hline
\end{tabular}

Tab. 2

Esterified fatty acids in blood after 20 months. Percentage distribution (means)

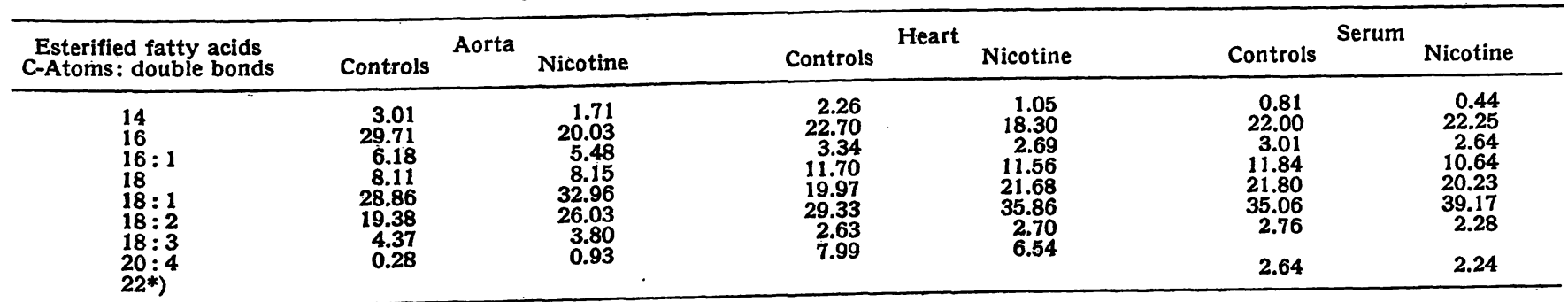

*) degree of saturation not known. 


\section{Histopathological findings}

Thoracic aorta: In 5 animals the intima showed changes: Thickening of the intima ( 3 treated animals), intima sclerosis ( 1 treated animal), and atheromatosis ( 1 control). Distinct medial sclerosis was found in 5 treated animals $^{\circ}$ and 3 controls.

Main arteries: Evident medial sclerosis was found in 2 treated animals, the aortas of which were without any degenerative alterations. In 2 treated animals and 4 controls there was a slight patchy thickening of the intima. In two cases only the sudan III staining was unsignificantly positive for lipid deposition in the intima (1 control and 1 treated animal).

Coronary arteries: Only 2 controls showed alterations which resembled medial sclerosis. In 15 controls and 9 treated animals perivascular and interstitial lymphohistiocytic infiltrations of various degree were found. In these sections alterations of coronary arteries with respect to intima proliferation could not be observed.

Renal arteries: 10 controls and 5 treated animals showed arteriolosclerosis, occasionally combined with slight arteriosclerosis.

Cerebral arteries: In 7 controls and 11 treated animals perivascular round cell infiltration was present.

Other organs: Liver sections of most animals (17 controls and 22 treated animals) showed round cell infiltrations in the periportal fields; in some animals proliferation of the bile ducts and centrolobular hyperaemia could be observed. In addition in 3 controls and 1 treated animal there was a diffuse and fine vacuolar fatty change of the liver. Degenerative alterations of the hepatic vessels could not be seen except for one case of subendothelial amyloidosis which was also found in the renal glomerula. Tubular nephrosis was found relatively often ( 7 controls and 12 treated animals) with reabsorbed pigment in the tubular epithelium and with intratubular calcification. In 19 animals (11 controls and 8 treated animals) interstitial round cell infiltrations were observed, sometimes combined with the above mentioned tubular nephrosis. The epithelium of the urinary bladder of only 4 controls was changed as in catarrhalic cystitis. Striated muscle of 1 control showed intramuscular calcification.

No remarkable changes were found in the sections of adrenal glands, pancreas, and intestine.

\section{Further results}

The calcium content of the aorta of the test group is significantly increased compared with the controls (fig. 5).

Table 3 shows the activities of several serum enzymes at the time of sacrifice of the animals. An increased activity of the amylase, acid phosphatase and cholinesterase and a decrease of the activity of lactate dehydrogenase in the treated animals can be seen. These changes, however, are statistically not significant and are within the normal range, when human values are taken for comparison.

A summary of the blood cell counts is given in tables 4 and 5 , there are no differences, except for a small

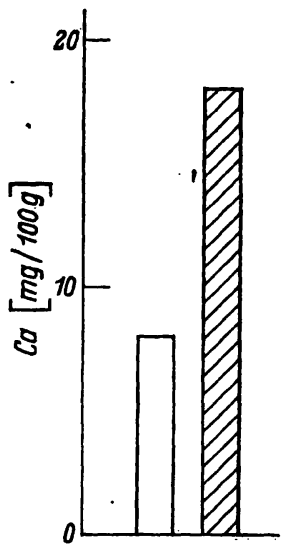

Fig. 5

Calcium content in aorta after 20 months. White bars: controls; hatched bars: treated

Tab. 3

Serum enzymes after 20 months (means $\pm S D$ )

\begin{tabular}{|c|c|c|}
\hline Enzyme $\mathrm{mU} / \mathrm{ml}$ & $\begin{array}{c}\text { Nicotine=treated } \\
\text { animals }\end{array}$ & Control animals \\
\hline $\begin{array}{l}\text { amylase } \\
\text { acid phosphatase } \\
\text { cholinesterase } \\
\text { lactate dehydrogenase } \\
\text { leucine amino peptidase } \\
\text { sorbitol dehydrogenase } \\
\text { alanine transaminase } \\
\text { aspartate transaminase } \\
\text { alkaline phosphatase }\end{array}$ & $\begin{array}{c}404 \pm 156 \\
(\mathrm{n}=15) \\
31.3 \pm 18.8 \\
(\mathrm{n} \equiv 18) \\
1.4 \pm 0.3 \\
(\mathrm{n} \equiv 18) \\
44.8 \pm 6.9 \\
(\mathrm{n}=18) \\
18.2 \pm 1.6 \\
(\mathrm{n}=18) \\
6.4 \pm 1.4 \\
(\mathrm{n}=18) \\
10.0 \pm 2.5 \\
(\mathrm{n} \equiv 18) \\
12.8=5.7 \\
(\mathrm{n}=17) \\
19.0 \pm 13 \\
(\mathrm{n}=18)\end{array}$ & $\begin{array}{r}272 \pm 176 \\
(n=12) \\
21.4 \pm 6.5 \\
(n=12) \\
0.76 \pm 0.2 \\
(n=12) \\
73.2 \pm 33.6 \\
(n=11) \\
21.6 \pm 6.9 \\
(n=11) \\
4.7 \pm 1.9 \\
(n=12) \\
11.7 \pm 3.5 \\
(n=12) \\
10.9 \pm 2.8 \\
(n=12) \\
18.0 \pm 7.3 \\
(n=12)\end{array}$ \\
\hline
\end{tabular}

Tab. 4

Erythrocytes, blood platelets, hemoglobin and hematocrit after 20 months (means $\pm \mathrm{SD}$ )

\begin{tabular}{|c|c|c|}
\hline Subject & $\begin{array}{l}\text { Nicotine-treated } \\
\text { animals }\end{array}$ & Control animals \\
\hline $\begin{array}{l}\text { erythrocyte count } \\
\text { millions per mm } \\
\text { hemoglobin } \\
\text { g/100 ml blood } \\
\text { volume of } \\
\text { erythrocytes } \mu \mathrm{m}^{3} \\
\text { hematocrit } \\
\text { Vol. \% } \\
\text { hemoglobin content of } \\
\text { single erythrocyte pg } \\
\text { blood platelets count } \\
\text { in } 1000 / \mathrm{mm}^{3}\end{array}$ & $\begin{aligned} & 4.3 \pm 1.2 \\
&(\mathrm{n}=17) \\
& 11.5 \pm 1.1 \\
&(\mathrm{n}=17) \\
& 90.7 \pm 57.0 \\
&(\mathrm{n}=17) \\
& 34.3 \pm 5.4 \\
&(\mathrm{n} \equiv 17) \\
& 30.6 \pm 21.0 \\
&(\mathrm{n}=17) \\
& 408.6 \pm 123.2 \\
&(\mathrm{n}=18)\end{aligned}$ & $\begin{aligned} & 4.4 \pm 0.8 \\
&(n=12) \\
& 11.4 \pm 0.7 \\
&(n=12) \\
& 81.0 \pm 20.0 \\
&(n=12) \\
& 35.6 \pm 10.8 \\
&(n=12) \\
& 26.1 \pm 4.4 \\
&(n=12) \\
& 391.7 \pm 78.3 \\
&(n=13)\end{aligned}$ \\
\hline
\end{tabular}

Tab. 5

Granulocytes, percentage distribution after 20 months (means)

\begin{tabular}{|c|c|c|}
\hline Leucocytes & $\begin{array}{l}\text { Nicotine-treated } \\
\text { animals }\end{array}$ & Control animals \\
\hline $\begin{array}{l}\text { leucocytes count } \\
\text { in } 1000 \text { per } \mathrm{mm}^{2} \text { blood }\end{array}$ & 3.9 & 2.9 \\
\hline $\begin{array}{l}\text { segmented cells } \\
\text { mature segmented } \\
\text { lymphocytes } \\
\text { eosinophiles } \\
\text { monocytes } \\
\text { basophiles }\end{array}$ & $\begin{array}{l}0 \\
21.1 \\
76.4 \\
1.4 \\
1.0 \\
0\end{array}$ & $\begin{array}{r}0.5 \\
8.8 \\
84.2 \\
4.4 \\
2.0 \\
0\end{array}$ \\
\hline
\end{tabular}


Tab. 6

Composition of serum proteins after 20 months (means and range)

\begin{tabular}{|c|c|c|c|c|c|c|c|}
\hline Test groups & $\underset{\text { rel.- } \%}{\text { Albumin }}$ & rel.- $\alpha_{1}$ & rel.- $\%$ & $\begin{array}{c}\text { Globulins } \\
\beta \\
\text { rel.- } \%\end{array}$ & $\stackrel{\gamma}{r}=\%$ & $\mathrm{~g} / 10^{y} \mathrm{~m} \mathrm{ml}$ & $\begin{array}{c}\text { Total } \\
\text { protein } \\
\text { g/100 ml }\end{array}$ \\
\hline control group $(n=13)$ & $59 \stackrel{66}{-71}$ & $4-11$ & $4 \stackrel{6}{9}$ & $7-12$ & $10-20$ & $0.65-1.34$ & $5.1-6.3$ \\
\hline nicotine-treated animals $(n=17)$ & $29-68$ & $2-\frac{6}{-10}$ & $3-24$ & $8 \stackrel{11}{-23}$ & $11-23$ & $0.54{ }^{1}-1.41$ & $\begin{array}{l}5.9 \\
4.9-7.1\end{array}$ \\
\hline
\end{tabular}

increase in segmented cells in the nicotine-treated group. Table 6 gives the composition of the serum proteins. The total protein is lower in the test group, obviously dependent on a decrease of the globulins. The concentrations of electrolytes, urea, and blood sugar of the test group resembled those of the controls (table 7). All these findings have, because of the slight deviations, as already mentioned, not been statistically tested. Therefore any kind of generalization seems to be impossible.

Tab. 7

Electrolytes, urea and blood sugar after 20 months (means \pm SD)

\begin{tabular}{lcr}
\hline blood component & $\begin{array}{c}\text { Nicotine-treated } \\
\text { animals }\end{array}$ & Control group \\
\hline calcium mval/l & $6.9 \pm 0.5$ & $6.9 \pm 0.4$ \\
sodium mval/l & $(\mathrm{n}=16)$ & $(\mathrm{n}=12)$ \\
potassium mval/l & $(\mathrm{n} \pm 16)$ & $(\mathrm{n} \pm 12)$ \\
urea mg/100 ml & $4.7 \pm 0.7$ & $4.3 \pm 0.7$ \\
$(\mathrm{n}=16)$ & $(\mathrm{n}=12)$ \\
blood sugar $\mathrm{mg} / 100 \mathrm{ml}$ & $29.7 \pm 17.9$ & $24.4 \pm 5.1$ \\
& $(\mathrm{n}=15)$ & $(\mathrm{n}=12)$ \\
& $229 \pm 73$ & $(\mathrm{n} \pm 56$ \\
& $(\mathrm{n}=16)$ &
\end{tabular}

\section{Discussion}

\section{Nicotine dosage and concentration}

Depending on methodical difficulties, there exist very few observations on the amount of nicotine absorbed from tobacco smoke by the human organism. From animal experiments and from nicotine estimations in human blood we can conclude that an average of not more than $1 \mathrm{mg}$ nicotine may be resorbed from one cigarette by inhaling (43). Under this assumption the nicotine dose used in this experiment would correspond to the dose a smoker is inhaling who smokes more than 100 cigarettes daily. Although the dosage used in this experiment is definitively lower than in most earlier investigations, it should be remembered that this dose is higher than can be expected even by heavy smokers.

\section{Fat metabolism}

The composition of blood fat shows a statistically significant alteration according to age, but no difference between controls and nicotine treated animals. The results with regard to the concentration of free fatty acids in serum are in fact statistically not significant, but seem to be worth repeating, because of the finding that the activity of the lipoprotein lipase of aortic tissue in the nicotine-treated animals is significantly elevated and these conditions may be an adaptation to increased lipolytic activity.

As mentioned already, nicotine has a marked lipolytic effect via release of catecholamines. This has been proved in our own experiments (44) and by Kershbaum and coworkers (9). This fact can explain the high concentration of free fatty acids in the serum and in organs, as well as the decrease of the concentration of neutral fat, especially in the liver. Nicotine therefore does not promote lipoidosis, on the contrary, it releases free fatty acids from triglycerides, according to its above mentioned metabolic actions. These results are in accordance with findings of CUNNINGHAM and FRIEND (45), who showed that the meat from nicotine treated pigs is protein-rich and poor in fat.

For the first time, we were able to show an increased activity of the lipoprotein lipase in heart and aorta under the influence of nicotine. This result seems to be an important point for further investigation. The activity of this enzyme in the blood of the nicotinetreated animals could not be estimated, because of the very low activity of the enzyme if not stimulated by heparin. Heparinization could not be performed because of the possible influence of heparin on other parameters to be measured.

It has been assumed, that a chronically elevated level of free fatty acids in the blood may lead to an elevated level of cholesterol via the $\beta$-oxidation of free fatty acids and subsequent disposition of $\mathrm{C}-2$ compounds for cholesterol synthesis. Our results do not favor this theory.

Our results are in accordance with findings of GuDBJARNASON (46), who, after nicotine administration to dogs, found basically the same results especially with regard to the concentration of fat metabolites in serum and organs. He moreover found an inhibition of cholesterol synthesis by nicotine and a significant prolongation of the half life of administered cholesterol in the nicotine treated animals.

Our results may explain the surprising results of other authors, mentioned in the introduction, that the level of triglycerides in the blood is decreased in smokers in long time and acute experiments. The increase of the activity of lipoprotein lipase may be the explanation of this phenomenon.

\section{Etiology of arteriosclerosis}

Our tesults show, that nicotine alone does not produce a lipoidosis even after prolonged administration to animals, who tend to spontaneous development of arteriosclerosis of the main arteries. On the contrary, nicotine acts lipolytically in accordance to its known pharmacological effect. ZEMPLÉNYI and coworkers (47) showed in rabbits an increased lipolytic activity in aortic tissue 
after cholesterol feeding; thus increased lipolytic activity does not seem to exclude sclerosis. The increase in the activity of lipoprotein lipase may be a consequence of a disturbed metabolism of the aortic wall which seems to be the case during sclerosation and which could be shown in several investigations on enzymes of the sclerotic vessel (for references see Platt (48)).

A very important finding in the present investigation is the significantly elevated calcium content of the aorta of the nicotine-treated animals, with no increase in the calcium concentration of the serum. Further investigations will be needed to confirm and to evaluate the mechanism of this finding. However, it seems that alterations in arterial tissues are biochemically demonstrable before changes can be shown histologically and that the estimation of the calcium content is a useful method for the estimation of the degree of calcification.

\section{Correlation between smoking and coronary beart disease}

Our results do supply some evidence for a possible participation of nicotine in an earlier manifestation of coronary heart disease in smokers. But considering the amount of nicotine administered in this experiment and possible differences in resorption between smokers and our experimental conditions, it seems to us not very likely that nicotine alone represents the "risk factor smoking" in coronary heart disease. In this connection, a paper by Hess and Frost (49) may be of some importance. These-authors demonstrated alterations in aortic intima with a new electron microscopic technique in rabbits after relatively short exposure to tobacco smoke and confirmed with these findings earlier results of Shrmamoro (50). It seems possible, that a prolonged nicotine action may produce calcification in tussues, altered by other constituents of tobacco smoke; therefore, further substances should be sought in tobacco smoke, which may be connected with this problem. In this connection, results of Astrup and coworkers (51) should be mentioned, who found heavy arterisclerotic alterations in the coronary arteries of rabbits, exposed to cholesterol feeding and an elevated concentration of carbon monoxide in the respiration air.

With regard to the toxicity of chronic nicotine administration, no indication of damage to organ systems has been found; especially noteworthy is the absence of pathological values for serum enzymes. TJAwOKIN (52) found an increased value of aspartate transaminase. We did not observe a change in aspartate transaminaseactivity, which correlates with the absence of histological findings.

A grant from the "Wissenschaftliche Forschungsstelle im Verband der Cigarettenindustrie, Hamburg" is gratefully acknowledged.

\section{References}

1. Smoking and Health. Report of the Advisory Committee to the Surgeon General of the Public Health Service. Public Health Service Publication No 1103, Washington DC (Terry Report) (1964). - 2. The Health Consequences of Smoking. A Public Health Service Review. U.S. Department of Health, Education and Welfare, Washington DC (1967). - 3. DoYLE, J.T., T. R. Dawber, W. B. Kannel, S. H. KINCH and H. A. KaHN, J. Amer. Med. Ass. 190, 886 (1964). - 4. Oberwitrler, W., Med. Welt 1968, 2478. - 5. Auerbach, O., E. HaMmoNd and L. GARFINKEL, N. England J. Med. 273, 775 (1965). - 6. WestFalt, T. C. and D. T. WAtrs, J. Appl. Physiol., Wash. 19, 40 (1964). 7. Schimid, E., N. A. Tautz, P. Winter and L. Zicha, Verh. Dtsch. Ges. inn. Med. 71, 701 (1965). - 8. Milton, A. S., Brit. J. Pharmacol. 26, 256 (1966). -9. Kershbaum, A., S. Bellet and J. Jiminez, J. Amer. med. Ass. 195, 1095 (1966). - 10. CzochraLysanowicz, A., M. Gorskr and M. Kedra, Ann. Univ. Mariae Curie-Sklodowska (Med.) 14, 181 (1959). - 11. ThIENes, C. H., Ann. N. Y. Acad. Sc. 90,239 (1960). - 12. HAss, G. M., W. LANDERholm and A. Hemmens, Circulation 34, Suppl. 3, p. 14 (Abstract) (1966). -13. Grosgogeat, Y. G., G. Anguera, J. Lellouch, B. Jacotot and J.-L. BEAumont, J. Atheroscler. Res. 5, 291 (1965). - 14. WenzeL, D. G. and G. L. BeCKLoff, J. Amer. Pharmaceut. Ass. Sc. ed. 57, 338 (1958). - 15. Gofman, J. W., F. T. Lindgren, B. Strisower, O.F. Delalla, F. Glazier and A. Tamplin, Geriatrics, Minneapolis 10, 349 (1955). - 16. Karvonen, M., E. Orma, A. Keys, F. FidanzA and J. Brozek, Lancet, London (1959/I, 492 - 17. Bronte-Stewart, B., Brit. Med. J. 1961/I 379. - 18. KANNEL, W. B., L. K. WIDMER and T. R. DAwBER, Schweiz. med. Wschr. 95, 18 (1965). - 19. Kershbaum, A., S. Beliet, E. R. Dickstein and L. J. Feinberg, Circulat. Res. 9, 631 (1961). - 20. Butkus, A. and I. H. PAgE, J. Amer. Med. Ass. 195, 138 (1965). - 21. Heyden, S., in: G. Schettler u. R. Sanwald, Epidemiologie der Koronargefäßerkrankungen. Pathophysiologische und klin. Aspekte des Fettstoffwechsels, Thieme, Stuttgairt (1966). - 22. Cramér, K., S. PaulnN and L. Werkö, Circulation 33, 888 (1966). - 23. Kontrinen, A. and M. RajA-
SAlmi, Brit. Med. J. 1963/I, 850. - 24. Engelberg, H., Circulation 34, Suppl. 3, p. 10 (Abstract) (1966). - 25. Duncombe, W. G., Biochem. J. 88, 7 (1963). - 26. WACHTER, B., Ärztl. Lab. 11, 11 (1965). - 27. Galetrr, F., Clin. chim. Acta (Amsterdam) 6, 749 (1961). - 28. Watson, D., Clin. chim. Acta (Amsterdam) 5, 637 (1960). - 29. Chabrol, C. and J. Charonnat, Presse méd., Paris 96, 1713 (1937). - 30. ZölLnER, N., and D. EBERHAGEN, Untẹtsuchung und Bestimmung der Lipoide im Blut, Springer (1965). 31. SChlenk, H. and J. H. GellermanN, Z. analyt. Chem. 303, 1412 (1960). - 32. Schieverbein, H., and K. GrundKe, Z. analyt. Chem. 237, 1 (1968). - 33. KARMEN, A., J. Clin. Invest. 34, 131 (1957). - 34. Wrobiewski, E. and J. S. LA Due, Proc. Soc. exp. Biol. Med. 91, 569 (1956). - 35. Hotzer, H., J. HAAN and S. SCHNEIDER, Biochem. Z. 326, 451 (1955). - 36. NAGEL, W., F. Wirlig and F. H. Schmidr, Klin. Wschr. 42, $447^{\circ}(1964)$. 37. Somogri, M., J. biol. Chemistry 125, 399 (1938). - 38. FishMAN, W. H., J. biol. Chemistry 200, 89 (1953). - 39. Bessery, O. A., O. H. LowrY and M. J. Brock, J. biol. Chemistry 164, 321 (1946). 40. Wroblewskr, E. and S. J. La Due, Proc. Soc. exp. Biol. Med 90, 210 (1955). - 41. Ferro, P. V. and A. B. Ham, Amer. J. Clin. Path. 28, 208, 689 (1957). - 42. SchmirerLöw, C. G. and E. HansSON, in: U.S. v. EULER, Tobacco alcaloids and related compounds, Pergamon Press, Oxford (1965). - 43. Schievelbein, H., in: H. Schievelben, Nikotin, Pharmakologie und Toxikologie des Tabakrauches, Thieme Stuttgart (1968). - 44. SchİvelubeIN, $H$. and V. Londong, unpublished. - 45. Cunningham, H. M. and D. W. FrIEND, J. Animal Sci. 24, 41 (1965). - 46. GudBjarnason, S., J. Pharmacol. Exper. Therap., Baltimore 161, 47 (1968). - 47. ZEMPLÉNYI, T., Z. LOJDA, O. MrHovi, in: SANDLER and Bourne, Atherosclerosis and its origin, Academic Press. New York, London (1963). - 48. PlatT, D., Med. Klin. 64, 1261 (1969). - 49. Hess, H. and H. Frost, Fortschr. Med. 86, 841 (1968). - 50. Shrmamoto, T., Asian med. J. 3, 479 (1960). 51. Astrup, P., K. KJELDSEN and J. WANSTRUP, J. Atherosclerosis Res. 7, 343 (1967), - 52. TJawoKIN, W. W., Virchows Arch. path. Anat. 346, 29 (1969).

Prof. Dr. H. Schievelbein, 8000 München 15, Nussbaumstr. 20 


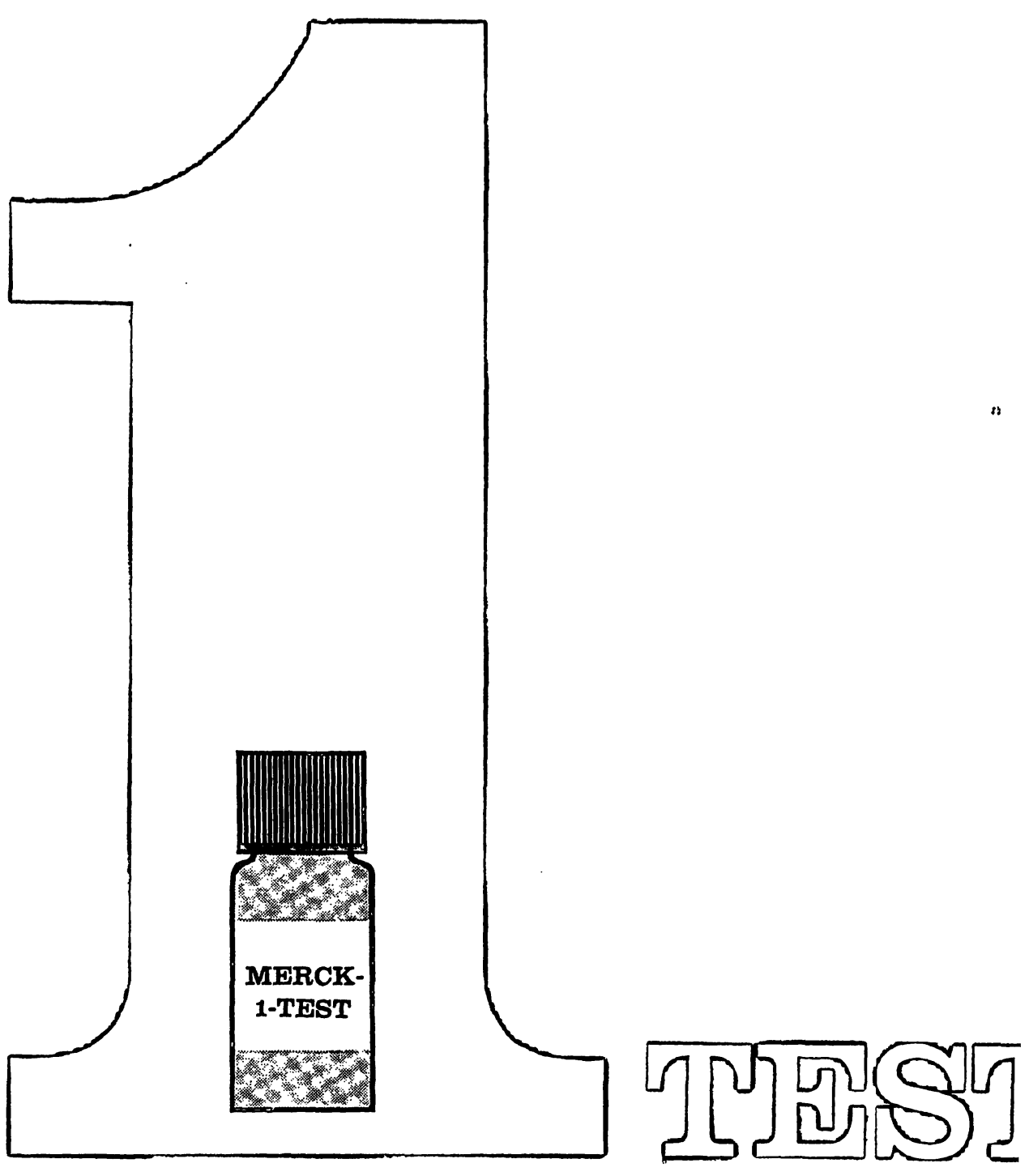

\section{Ein Test in einem Gle}

Cholinesterase

GOT (UV)

GPT (UV)

HBDH (UV)

LDH (UV)

Eine neue Konzeption für Sicherheit

und Zeitersparnis in Klinik- und

Praxislabor

Merck-1-Test-Gläser sind optimal

verschlossen und im Handumdrehen zu öffnen.

Lösungsmittel in der Packung

enthalten; daher kein destiliiertes

Wasser notwendig 


\section{Sigma bietet an: \\ Lipid-Standards \\ hoher Reinheit für die Chromatographie}

Gemische bekannter quantitativer Zusammensetzung, geeignet als Bezugssubstanzen

für Dünnschicht- und Gaschromatographie. Alle Bestandteile sind $99 \%$ rein.

Gesamtinhalt jeder Ampulle: $100 \mathrm{mg}$ - Preis: $\$ 9,75$

Lager-Nummer

\begin{tabular}{|c|c|c|c|c|c|c|c|c|c|c|c|c|}
\hline & \\
\hline & \begin{tabular}{|c|}
$189-7$ \\
$20 \mathrm{mg}$ \\
von
\end{tabular} & $\begin{array}{c}189-3 \\
20 \mathrm{mg} \\
\text { von }\end{array}$ & $\begin{array}{c}189-8 \\
20 \mathrm{mg} \\
\text { von }\end{array}$ & $\begin{array}{c}189-6 \\
20 \mathrm{mg} \\
\text { von }\end{array}$ & $\begin{array}{l}189-1 \\
20 \mathrm{mg} \\
\text { von }\end{array}$ & $\begin{array}{c}189-2 \\
20 \mathrm{mg} \\
\text { von }\end{array}$ & $\begin{array}{c}189-5 \\
25 \mathrm{mg} \\
\text { von }\end{array}$ & $\begin{array}{c}189-4 \\
25 \mathrm{mg} \\
\text { von }\end{array}$ & $\begin{array}{c}189-9 \\
20 \mathrm{mg} \\
\text { von }\end{array}$ & $\begin{array}{c}178-1 \\
20 \mathrm{mg} \\
\text { von }\end{array}$ & $\begin{array}{c}178-4 \\
25 \mathrm{mg} \\
\text { von }\end{array}$ & $\begin{array}{c}178-3 \\
331 / 8 \mathrm{mg} \\
\text { von }\end{array}$ \\
\hline \multicolumn{13}{|l|}{ Fettsäure-Methylester der } \\
\hline 8:0 Capryl-, Ocfansäure & 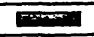 & En. & & & & & & & & & & \\
\hline 9:0 Pelargon-, Nonansäure & 0 & & & & & & & & & & & \\
\hline 10:0 Caprin-, Decansäure & nand & $=$ & & & & & & & & & & \\
\hline 11:0 Undecyl-, Undecansäure & एक्लि & & & & & & & & & & & \\
\hline 12:0 Laurin-, Dodecansäure & $=$ & rexteren & & & & & & & & & & \\
\hline Tridecansäure & & & Fes & 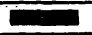 & & & & & & & & \\
\hline 14:0 Myristin-, Tetradecansäure & & $=$ & 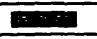 & & & & & & & & & \\
\hline 15:0 Pentadecansäure & & & Non & 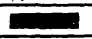 & & & & & & & & \\
\hline 16:0 Palmitin-, Hexadecansäure & & s. & was & & 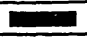 & $\therefore$ & $\square$ & & & & & \\
\hline \multicolumn{13}{|c|}{ 16:1 Palmit-öl (-olein)-, Zoomarinsäure } \\
\hline 17:0 Margarin-, Heptadecansäure & & & Din & $=$ & & & & & & & & \\
\hline \multicolumn{13}{|l|}{ 18:0 Stearin-, Octadecansäure } \\
\hline \multicolumn{13}{|l|}{ 18:1 Ölsäure } \\
\hline \multicolumn{13}{|l|}{ 18:2 Linolsäure } \\
\hline \multicolumn{13}{|l|}{ 18:3 Linolsäure } \\
\hline Nonadecansäure & & & & 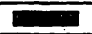 & & & & & 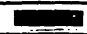 & & & \\
\hline \multicolumn{13}{|l|}{ 20:0 Arachin-, Eikosansäure } \\
\hline 11-Eikosensäure & & & & & & & & & $=$ & & & \\
\hline Heneikosansäure & & & & F & & & & & + & & & \\
\hline 22:0 Behen-, Dokosansäure & & & & & & & $x$ & & $\longrightarrow$ & & & \\
\hline 22:1 Erucasäure & & & & & & & & $\square$ & & & & \\
\hline \multicolumn{13}{|l|}{ Weifere Lipide } \\
\hline Ölsäure & & & & & & & & & & 5 & ש & \\
\hline Methyloleat & & & & & & & & & & in & & \\
\hline Cholesferin & & & & & & & & & & 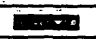 & $=0$ & \\
\hline Cholesteryloleat & & & & & & & & & & an & -1 & \\
\hline Triolein & & & & & & & & & & a & $\therefore$ & \\
\hline Monopalmitin & & & & & & & & & & & & 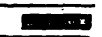 \\
\hline Dipalmitin & & & & & & & & & & & & 5 \\
\hline Tripalmitin & & & & & & & & & & & & Fan \\
\hline
\end{tabular}

Alle oben aufgeführten Lipide sind auch einzeln erhältlich. Zahlreiche weitere Lipide finden Sie in unserem Hauptkatalog. Gern stellen wir spezielle Gemische für Ihre speziellen Erfordernisse zusammen.

Achtung! Sigmas bereits phantastischer Kundendienst ist nun noch phantastischer. Unsere erstaunlich bemühte Bestellungskontrolle und Versandstelle haben jetzt ihre Wochenenden aufgegeben, um jeden Tag, auch Samstag und Sonntag, den Routine-Versanddienst zu versehen.

Sigma-Reagenzien sind in der ganzen Welt durch den Fachhandel oder direkt aus St. Louis beziehbar.

Telegramme: SIGMACHEM, St. Louis, Missouri

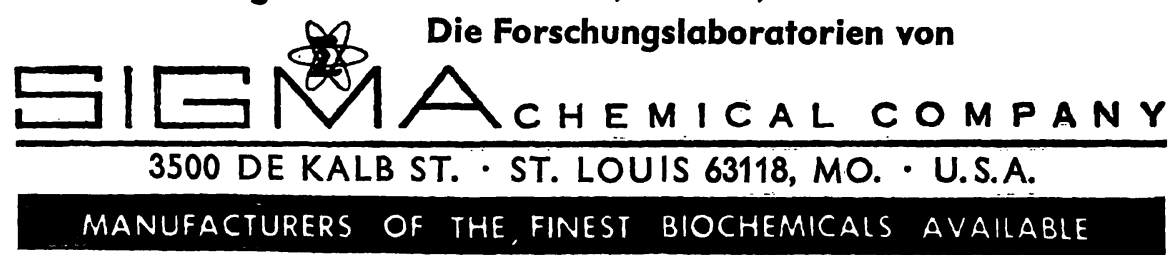

Vertretung in England:

SIGMA LONDON Chem, Co. Ltd

12, Lettice St., London S. W. 6 ENG.

Telephone: RENown-5823 (Rückberechnung) 